\title{
Corrections
}

\section{Numular headache: A coin-shaped cephalalgia}

In the article "Numular headache: A coin-shaped cephalalgia" (Neurology 2002;58:1678-1679) by Pareja et al., the word "numular" should have been spelled "nummular." The publisher apologizes for this error.

\section{Cardiac adverse effects associated with mitoxantrone (Novantrone) therapy in patients with MS}

In the article "Cardiac adverse effects associated with mitoxantrone (Novantrone) therapy in patients with MS" (Neurology 2002;59:909-913) by Ghalie et al., there is an error in the dosage listed on page 910, under the Results section. The beginning of the second paragraph of the Results section should read as follows: Phase 3 trial of MITO in MS (MIMS trial). Of the 124 patients who received MITO in the MIMS trial, 64 received $5 \mathrm{mg} / \mathrm{m}^{2}$ MITO and 60 received $12 \mathrm{mg} / \mathrm{m}^{2}$ MITO every 3rd month for up to 2 years." The publisher apologizes for this error.

\section{A novel locus for inherited myoclonus-dystonia on 18p11}

In the article "A novel locus for inherited myoclonus-dystonia on 18p11" (Neurology 2002;59:1183-1186) by Grimes et al., one of the authors' names was inadvertenly misspelled. The author's name should read as follows: P. St. George-Hyslop. The publisher apologizes for the error. 


\section{Neurology}

\section{To: Cardiac adverse effects associated with mitoxantrone (Novantrone) therapy in patients with MS \\ Neurology 2003;60;157 \\ DOI 10.1212/WNL.60.1.157-a}

\section{This information is current as of January 14, 2003}

\section{Updated Information \&}

Services

Permissions \& Licensing

Reprints including high resolution figures, can be found at: http://n.neurology.org/content/60/1/157.2.full

Information about reproducing this article in parts (figures,tables) or in its entirety can be found online at:

http://www.neurology.org/about/about_the_journal\#permissions

Information about ordering reprints can be found online:

http://n.neurology.org/subscribers/advertise

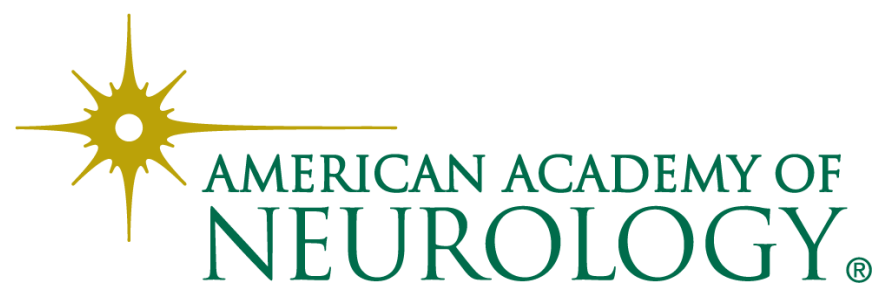

